$\begin{array}{ll}\text { Abstracta Iranica } & \begin{array}{l}\text { Abstracta Iranica } \\ \text { Revue bibliographique pour le domaine irano-aryen }\end{array} \\ & \text { Volume } 22 \mid \mathbf{2 0 0 1} \\ & \text { Comptes rendus des publications de } 1999\end{array}$

\title{
Haqiqat dā day. Peshawar, 1998, 129 p. [Voilà la vérité]
}

\section{Nadjib Manalaï}

\section{(2) OpenEdition}

1 Journals

\section{Édition électronique}

URL : http://journals.openedition.org/abstractairanica/37198

DOI : 10.4000/abstractairanica.37198

ISSN : 1961-960X

Éditeur :

CNRS (UMR 7528 Mondes iraniens et indiens), Éditions de l'IFRI

\section{Édition imprimée}

Date de publication : 15 mai 2001

ISSN : 0240-8910

\section{Référence électronique}

Nadjib Manalaï, « Haqiqat dā day. Peshawar, 1998, 129 p. [Voilà la vérité] », Abstracta Iranica [En ligne], Volume 22 | 2001, document 583, mis en ligne le 17 février 2010, consulté le 13 octobre 2020. URL http://journals.openedition.org/abstractairanica/37198; DOI : https://doi.org/10.4000/ abstractairanica.37198

Ce document a été généré automatiquement le 13 octobre 2020.

Tous droits réservés 


\title{
Haqiqat dā day. Peshawar, 1998, 129 p. [Voilà la vérité]
}

\author{
Nadjib Manalaï
}

1 Poța xəzāna (trésor caché) est une anthologie de poètes pachtounes écrite au $18^{\mathrm{e}} \mathrm{s}$. Depuis sa découverte dans les années 1940, il est devenu la principale référence pour la poésie pachto antérieure au $16^{\mathrm{e}} \mathrm{s}$. Certains auteurs européens (par ex. D. N. Mackenzie [50 voir Abs. Ir., 20-21, c.r. $\mathrm{n}^{\circ}$ 820) et quelques auteurs pachtophones (du Pakistan) remettent en cause l'authenticité de l'ouvrage. Qalandar Momand est le chef de file des détracteurs de Poța xəzāna au Pakistan.

2 Sa'id Gawhar a publié en 1996 un ouvrage intitulé Pota xəzāna fil haqiqat « Poța xəzāna en vérité » dans lequel il soutient le point de vue de Qalandar Momand.

3 Hameš Xalil, l'une des figures les plus en vue de la recherche pachto au Pakistan, soutient l'authenticité de Pața xəzāna et réfute les arguments de Sa'id Gawhar en mettant en évidence les faiblesses de son argumentation et l'inexactitude de ses affirmations.

\section{INDEX}

Thèmes : 11.2. Littérature pashto et dari (Afghanistan)

\section{AUTEURS}

NADJIB MANALAÏ

INALCO - Paris 